\title{
Lignocaine: effect on coronary blood flow in patients with recent myocardial infarction
}

Sir:

I wish to supplement the list of references to the paper of Gould et al. (1974) 36, 566-568. The results of their clinical experimental study on patients with recent myocardial infarction and of our clinical observations are similar in many respects in spite of the different methods used.

Dr. Sándor Széplaki, Department of Cardiology, 5th District Policlinic, I075 Budapest, Madách-tér 2, Hungary.

\section{References}

Széplaki, S. (1971). A Lidocain antianginás, antiischaemiás hatása. Orvosi hetilap, 112, 1217.

Széplaki, S., Szmandra, J., and Széplaki, Z. (1972). LidocainBehandlung bei Koronarischämie und Angina pectoris. Münchener medizinische Wochenschrift, 114, 1997.

Széplaki, S., Szilágyi, A., Széplaki, Z., Böszörményi, E., Barsi, B., and Máté, K. (1973). Anti-ischemic effect of Lidocain in the acute state of myocardial infarction. Agressologie, 14, 339. 